\title{
Pythium insidiosum colitis in a dog: treatment and clinical outcome
}

\author{
Colite por Pythium insidiosum em um cão: tratamento e evolução clínica
}

\author{
Mahyumi Fujimori ${ }^{I}$ Erika Rondon Lopes ${ }^{\text {II }}$ Samara Rosolem Lima ${ }^{I I}$ \\ Daphine Ariadne Jesus de Paula ${ }^{I}$ Arleana do Bom Parto Ferreira de Almeida ${ }^{\text {IV }}$ \\ Edson Moleta Colodel ${ }^{\text {IV }}$ Caroline Argenta Pescador $^{\text {IV }}$ Pedro Eduardo Brandini Néspoli ${ }^{\text {IV }}$ \\ Luciano Nakazato ${ }^{\mathrm{IV}}$ Valéria Dutra ${ }^{\mathrm{IV}}$ Roberto Lopes de Souza ${ }^{\mathrm{IV}}$ Valéria Régia Franco Sousa $^{\mathrm{IV}^{*}}$
}

ABSTRACT

The aim of this report is to describe the clinical, pathological and imaging findings and treatment of colitis caused by Pythium insidiosum in a canine presenting haematochezia and progressive weight loss. Through imaging, a thickening of the transverse and descending colon was observed. Histopathological analysis of the large intestine fragment revealed the presence of hyphae, confirmed by immunohistochemistry and PCR as $\boldsymbol{P}$. insidiosum. Antifungal treatment with itraconazole implemented after partial surgical resection, resulted in control of the disease.

Key words: intestinal pythiosis, PCR, immunohistochemistry, canine.

RESUMO

O objetivo deste relato é descrever os achados clínico-patológicos, de imagem e o tratamento de colite por Pythium insidiosum em canino apresentando hematoquezia e emagrecimento progressivo. Nos exames de imagem, foram observados espessamento do cólon transverso e descendente. Análise histopatológica de fragmento do intestino grosso revelou a presença de hifas, confirmado pela imuno-histoquímica e PCR como P. insidiosum. Terapia antifúngica com itraconazol foi instituída pós-ressecção cirúrgica parcial, obtendo-se controle da doença.

Palavras-chave: pitiose intestinal, $P C R$, imuno-histoquímica, canino.

\section{INTRODUCTION}

Pythiosis is a chronic pyogranulomatous disease of subcutaneous tissue in humans and animals, especially horses and dogs, caused by the oomycete Pythium insidiosum (GROOTERS, 2003). P. insidiosum infective propagules develop in aquatic environments and cause disease by invading the skin or intestinal mucosa (SANTURIO et al., 2006). In dogs, the gastrointestinal form is the most common and affects mostly young males of medium and large breeds. Clinical signs include vomiting, diarrhoea, progressive weight loss, abdominal pain and a palpable mass in the abdomen (HUNNING et al., 2010). These clinical signs along with chronic gastrointestinal illness are commonly observed in dogs with pythiosis (GROOTERS, 2003). However, definitive diagnosis is based on the isolation of $\boldsymbol{P}$. insidiosum by culture and/or by serological, immunohistochemistry (IHC) and PCR techniques (UBIALI et al., 2013).

The absence of ergosterol in the plasma membrane reduces the effectiveness of antifungal therapy. However, surgical excision followed by immunotherapy and the use of antifungal agents

\footnotetext{
IMédica Veterinária Autônoma, Cuiabá, MT, Brasil.

IIPrograma de Pós-graduação em Biociência Animal, Faculdade de Zootecnia e Engenharia de Alimentos (FZEA), Universidade de São Paulo (USP), Pirassununga, São Paulo, Brasil.

IIIPrograma de Pós-graduação em Ciência Veterinárias, Faculdade de Agronomia Medicina Veterinária e Zootecnia (FAMEVZ), Universidade Federal de Mato Grosso (UFMT), Cuiabá, MT, Brasil.

${ }^{\text {IV }}$ Departamento de Clínica Médica Veterinária (CLIMEV), Faculdade de Agronomia Medicina Veterinária e Zootecnia (FAMEVZ), Universidade Federal de Mato Grosso (UFMT), Avenida Fernando Correa da Costa, 2367, Boa Esperança, 78060-900, Cuiabá, MT, Brasil. E-mail: valeriaregia27@gmal.com. "Corresponding author.
} 
had been employed as treatments (SANTURIO et al., 2006; PEREIRA et al., 2010). The purpose of this report was to describe the clinical, pathological, imaging and therapeutic findings of one case of $\boldsymbol{P}$. insidiosum colitis in a dog.

At the Veterinary Hospital of the Universidade Federal do Mato Grosso, Cuiabá campus, a recently adopted midsize male canine, aged 16 months old, mixed breed, was attended. The clinical examination found haematochezia and progressive weight loss. Changes in complete blood count, kidney and liver biochemistry, urinalysis and faecal exam were not observed. Transabdominal ultrasound showed thickened and irregular walls (approximately $1.4 \mathrm{~cm}$ ) in the large intestine, and the heterogeneous aspect and decreased intestinal lumen were suggestive of colitis. Simple and contrast radiographs showed decreased motility in the large intestine and sharp reduction of the gut lumen with thickening of the transverse colon and cranial third of the descending colon.

Subsequently, four centimetres of the large intestine and two mesenteric lymph nodes were excised, followed by enteroanastomosis. Macroscopic examination revealed mild luminal narrowing and marked thickening of the wall, with areas of necrosis of the mucosa. Lymph nodes showed no macroscopic changes. Microscopically, the lesions in the intestine were characterized as multifocal, moderate mucosal and serosal eosinophilic necrosis containing sparsely septate tubuliform hyphae (Figure 1A and B). This necrosis was surrounded by a marked inflammatory infiltrate containing large amounts of neutrophils and eosinophils and scarce macrophages and giant cells. Fibrous connective tissue proliferation was also present in the lesion. Histological sections stained with Grocott's methenamine silver demonstrated the presence of large amounts of hyphae, within the areas of eosinophilic necrosis (Figure 1C).

Diagnosis was confirmed by IHC polyclonal anti-P. insidiosum antibodies produced by subcutaneous inoculation of zoospores of $\boldsymbol{P}$. insidiosum according to UBIALI et al. (2013), with strong marking of the $\boldsymbol{P}$. insidiosum hyphae (Figure 1D). The chromogen used was Permanent Red through the avidin-streptavidin method conjugated to alkaline phosphatase. For molecular analysis, a fresh intestinal fragment was macerated with liquid nitrogen, and then DNA extraction was performed using the phenol-chloroform method. PCR with primers PI1: 5'-TTCGTCGAAGCGGACTGCT-3' and PI-2: 5'-GCCGTACAACCCGAGAGTCATA-3' encoding the gene sequence ITS1 rDNA of $\boldsymbol{P}$. insidiosum
(UBIALI et al., 2013) was positive, as indicated by the amplification fragment $105 \mathrm{pb}$.

Initially, the patient was treated with potassium iodide, $40 \mathrm{mg} \mathrm{kg}^{-1}$ every 8 hours for 60 days, with no signs of remission. Thereafter, treatment was instituted with $10 \mathrm{mg} / \mathrm{kg}$ itraconazole, associated with $30 \mathrm{mg} \mathrm{kg}^{-1}$ terbinafine, every 24 hours for 160 days. However, one week after beginning the new protocol, the terbinafine treatment was descontinued, and itraconazole maintained. Ultrasound and radiographic evaluations were performed at 30,60, 90 and 120 days of treatment, showing gradual remission of the large bowel thickening, until complete regression achieved the fourth month of treatment (approximately $0.23 \mathrm{~cm}$ ). After one year the patient showed weight gain with remission of clinical signs.

Pythiosis in dogs primarily affects the skin and the gastrointestinal tract and had been linked to contact with wetlands (BERRYESSA et al., 2008; HUNNING et al., 2010); however, the form of infection in this case was unclear because the canine had been abandoned; thus, it was not possible to associate these data. According to RODRIGUES et al. (2006), pythiosis in dogs had been more commonly reported in young animals, males and large breeds, characteristics similar to our case.

Clinical signs of pythiosis vary according to the lesion location in the gastrointestinal system. Vomiting, diarrhoea, progressive weight loss and abdominal pain are frequently observed (HUNNING et al., 2010). However, this canine showed weight loss and haematochezia, which is related to the image findings of the transverse colon thickening and luminal reduction (GRAHAM et al., 2000). Although mass palpation in the gastrointestinal system (SANTURIO et al., 2006) is common and described in $60 \%$ of dogs (BERRYESSA et al., 2008), this feature was observed.

Segmental lesions characterized by the thickening of a portion of the large intestine were observed in radiographic and sonographic examination, as reported by GRAHAM et al. (2000), who described predominantly focal lesions especially involving the stomach, duodenum and colon.

The histopathological findings observed in this case featured a necro-eosinophilic pattern. This finding is similar to that reported by MARTINS et al. (2012), whose findings point to two types of histological patterns in dogs with intestinal injuries caused by $\boldsymbol{P}$. insidiosum: the granulomatous and necro-eosinophilic. This lesion pattern differed from those observed in $\boldsymbol{P}$. insidiosum infections in horses and cattle, where eosinophilic dermatitis, 


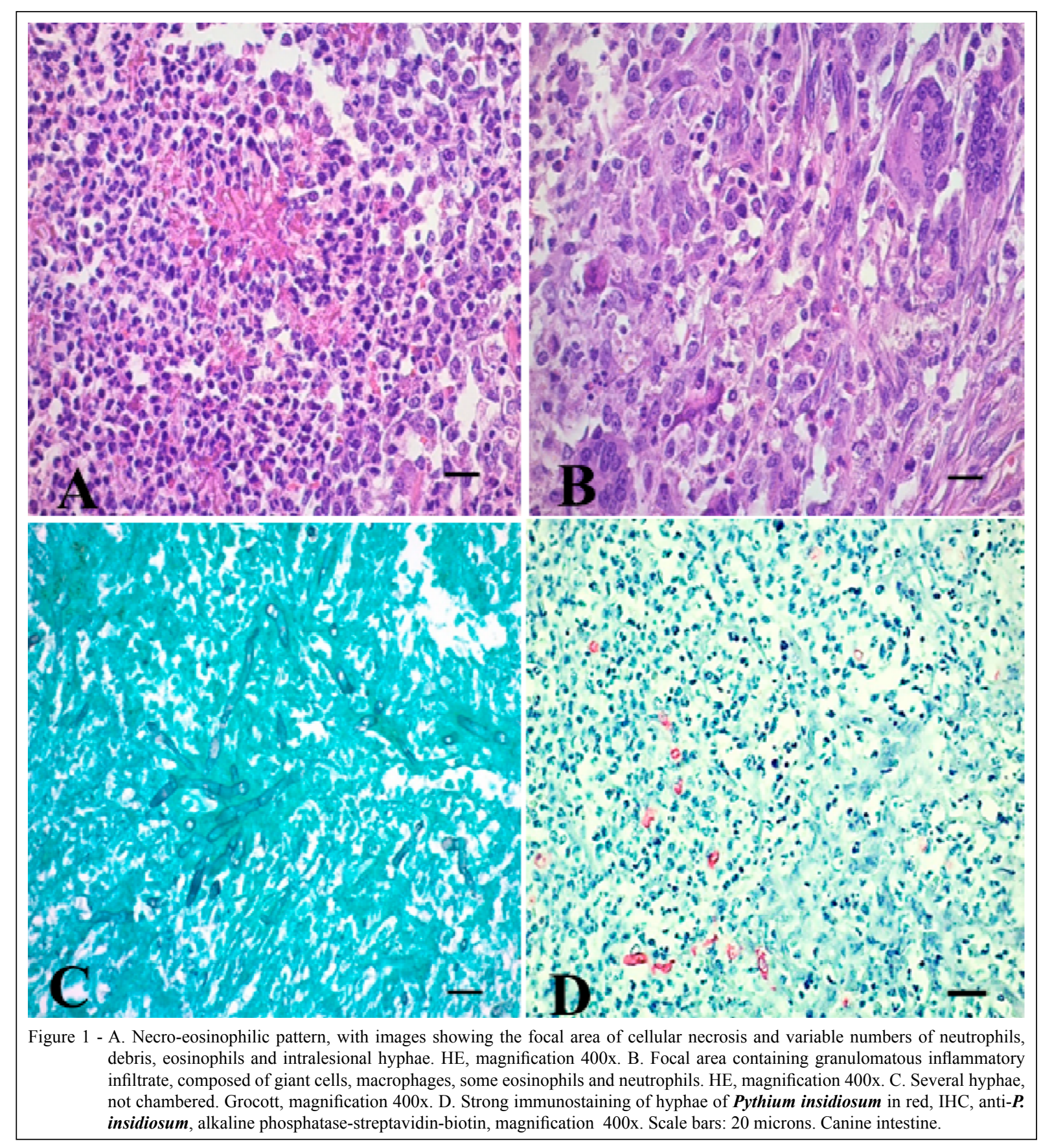

formation of early stages of kunkers and reactions in Splendori Hoeppli are associated with to granulomas in different degrees. According to GROOTERS (2003), histological findings of pythiosis in dogs can be confused with other oomycete infections. Thus, it becomes necessary to adopt diagnostic methods such as culture, serology, DNA detection by PCR and IHC. In this study, we used the IHC technique using anti-P. insidiosum antibodies (UBIALI et al., 2013), which showed great importance in the confirmation of the disease in cases in which culture is not possible (HUNNING et al., 2010). PCR using a specific primer for $\boldsymbol{P}$. insidiosum allowed confirmation of the species, which, according to UBIALI et al. (2013), proved to be effective in identifying $\boldsymbol{P}$. insidiosum in clinical samples of animals from different regions of Brazil.

The absence of ergosterol in the cytoplasmic membrane hinders the treatment of

Ciência Rural, v.46, n.3, mar, 2016. 
pythiosis. However, surgical resection and the use of antifungal drugs have shown good results in some cases (HUNNING et al., 2010; PEREIRA et al., 2013). This canine was initially given potassium iodide for the treatment, as this drug was previously described as a treatment option (ALVAREZ et al., 2013); however, the poor response to this treatment led to the replacement of potassium iodide with itraconazole associated with terbinafine. Some authors showed good success rates with this therapy (HUNNING et al., 2010; PEREIRA et al., 2010) because these drugs possess a synergistic effect when used together. Despite the early cessation of the use of terbinafine by the owner, the use of itraconazole associated with partial surgical excision allowed the remission of clinical signs, with no recurrence of the symptoms after one year. These results are similar to that described by SCHMIEDT et al. (2012), with the exception that immunotherapy was not applied in the present report. Other antifungal associations, combined with antibacterial treatments, were reported (JESUS et al., 2014); however, in this case, ampicillin and metronidazole were administered previously and in the immediate postoperative period for only nine days concomitant to potassium iodide, as these antibacterial classes were not cited as promising drugs for controlling pythiosis.

The clinical, pathological, imaging and molecular findings of colitis caused by $\boldsymbol{P}$. insidiosum are similar to those described in the literature. Therapy with itraconazole after partial surgical resection showed to be effective in controlling the disease.

\section{BIOETHICS AND BIOSSECURITY COMMITTE APPROVAL}

This report me with an animal runs in the routine of University Veterinary Hospital - Universidade Federal do Mato Grosso (UFMT), Cuiaba - and was not part of any project, with only one case report.

\section{REFERENCES}

ALVAREZ, J.C. et al. Equine skin pythiosis: a review. Revista CES Medicina Veterinária y Zootecnia, v.8, n.1, p.104-113, 2013. Available from: <http://www.scielo.org.co/pdf/cmvz/v8n1/ v8n1a09.pdf $>$. Accessed: May 28, 2014.

BERRYESSA, N.A. et al. Gastrointestinal pythiosis in 10 dogs from California. Journal of Veterinary Internal Medicine, v.22, p.1065-1069, 2008. Available from: <http://www.ncbi. nlm.nih.gov/pubmed/18647164>. Accessed: Apr. 18, 2014. doi: 10.1111/j.1939-1676.2008.0123.x.

GRAHAM, J.P. et al. Ultrasonographic features of canine gastrointestinal pythiosis. Veterinary Radiology \& Ultrasound, v.41, n.3, p.273-277, 2000. Available from: <http://www.ncbi. nlm.nih.gov/pubmed/10850879>. Accessed: May 28, 2014. doi: 10.1111/j.1740-8261.2000.tb01490.x

GROOTERS, A.M. Pythiosis, lagenidiosis, and zygomicosis in small animals. Veterinary Clinics of North America: Small Animal Practice, v.33, p.695-720, 2003. Available from: $<\mathrm{http}: / /$ www.sciencedirect.com/science/article/pii/S0195561603000342>. Accessed: Feb. 18, 2014. doi: 10.1016/S0195-5616(03)00034-2.

HUNNING, P.S. et al. Intestinal obstruction by Pythium insidiosum in a dog: case report. Arquivo Brasileiro de Medicina Veterinária e Zootecnia, v.62, n.4, p.801-805, 2010. Available from: <http://www.scielo.br/scielo.php?script=sci_ar ttext\&pid=S0102-09352010000400006>. Accessed: Feb. 18, 2014. doi: 10.1590/S0102-09352010000400006.

JESUS, F.P. et al. In vitro synergism observed with azithromycin, clarithromycin, minocycline, or tigecycline in association with antifungal agents against Pythium insidiosum. Antimicrobial Agents and Chemotherapy, v.58, n.9, p. 5621-5625, 2014. Available from: <http://www. ncbi.nlm.nih.gov/pubmed/25001300>. Accessed: Apr. 10, 2015. doi: 10.1128/AAC.02349-14.

MARTINS, T.B. et al. A comparative study of the histopathology and immunohistochemistry of pythiosis in horses, dogs and cattle. Journal of Comparative Pathology, v.146, n.2-3, p.122-131, 2012. Available from: <http://www. ncbi.nlm.nih.gov/pubmed/21824626>. Accessed: Apr. 14, 2015. doi: 10.1016/j.jcpa.2011.06.006.

PEREIRA D.I.B. et al. Cutaneous and gastrointestinal pythiosis in a dog in Brazil. Veterinary Research Communications, v.34, p.301-306, 2010. Available from: <http://www.ncbi. nlm.nih.gov/pubmed/20306346>. Accessed: Jun. 28, 2014. doi: $10.1007 / \mathrm{s} 11259-010-9354-9$.

PEREIRA, D.I.B. et al. Canine gastrointestinal pythiosis treatment by combined antifungal and immunotherapy and review of published studies. Mycopathologia, v.176, p.309-315, 2013. Available from: $<$ http://www.ncbi.nlm.nih.gov/pubmed/23918089>. Accessed: Jun. 20, 2014. doi: 10.1007/s11046-013-9683-7.

RODRIGUES, A. et al. Intestinal dog pythiosis in Brazil. Journal de Mycologie Médicale, v.16, p.37-41, 2006. Available from: $<$ http:// www.sciencedirect.com/science/article/pii/S1156523306000059>. Accessed: Jun. 20, 2014. doi: 10.1016/j.mycmed.2005.10.006.

SANTURIO, J.M. et al. Pythiosis: an emergent mycosis. Acta Scientiae Veterinariae, v.34, p.1-14, 2006. Available from: <http:// www.ufrgs.br/actavet/34-1/artigo646.pdf>. Accessed: Jun. 20, 2014.

SCHMIEDT, C.W. et al. Treatment of intestinal pythiosis in a dog with a combination of marginal excision, chemotherapy, and immunotherapy. Journal of the American Veterinary Medical Association, v.241, n.3, p.358-363, 2012. Available from: $<$ http:// www.ncbi.nlm.nih.gov/pubmed/22812473>. Accessed: Apr. 10, 2015. doi: $10.2460 /$ javma.241.3.358

UBIALI, D.G. et al. Pathology of nasal infection caused by Conidiobolus lamprauges and Pythium insidiosum in sheep. Journal of Comparative Pathology, v.149, 137145, 2013. Available from: <http://www.ncbi.nlm.nih.gov/ pubmed/23375916>. Accessed: Jun. 20, 2014. doi: 10.1016/j. jcpa.2012.12.002. 